\title{
"Beyond Refuge": Post Acceptance Challenges in New Identity Constructions of African Refugee Claimants in Canada
}

\author{
Michael Baffoe, M.S.W; Ph.D \\ Assistant Professor of Social Work \\ University of Manitoba \\ $500 B$ Tier Building, Winnipeg, $M B, R 2 N 2 X 2$, Canada. \\ Tel: (204) 474-9682, Fax:(204) 474-7594 \\ e-mail: Michael.Baffoe@ad.umanitoba.ca
}

Doi:10.5901/ajis/2013.v2n1p215

Abstract

Undergoing the process of refugee claims and refugee determination in Canada is not easy: It involves long periods of waiting and uncertainty when the focus of the claimants is only on getting their claims "accepted". The period after acceptance of refugee claims however, involves a difficult process of rebuilding distupted and (in some cases), "shattered" lives, in "safety and dignity". While government and mainstream settlement agencies focus on housing, language training and employment as the immediate and important settlement needs of new immigrants and refugees, the refugees themselves undergo very difficult processes of reconstructing new identities as part of their efforts to carve new ways of life for themselves and their families. They are eager to shed the refugee label/tag and take on new identities as they navigate their way through their new society. This article highlights findings from studies done with Africans who arrived as refugees and refugee claimants in Montreal and Toronto from the late I980sto the mid I990s, most of whom are now either permanent residents or Canadian citizens.

Key Words: Africa, Refugees, re-settlement; new identity constructions, mental health, stigmatization. Labelling; counter-storytelling

\section{Introduction}

With the changes in the geo-political landscapes around the world and political, economic and social upheavals, many people continue to find themselves at risk and seek asylum outside of their own borders (UNHCR, 1997c). This is involuntary or forced migration and many of such people who become known as refugees continue to seek protection and humanitarian assistance in other countries around the world. The UN Convention on Refugees emphasizes that the determination of refugee status reflects an incompatibility between the applicant and his/her state or country of origin (Boyd, I999; Connors, 1997).

Forced migration and its resultant turning of people into refugees have been an important component of international migration in Africa. The number of refugees in Africa increased steadily from 1960 to 1995 , passing from 79,000 to 6.4 million in that period. Since 1970, refugees in Africa have constituted a substantial proportion of the world's refugees. The proportion of refugees in Africa peaked in 1975, when three out of every five of the world's refugees had found asylum in the continent. Since 1985, at least a third of all refugees in the world have been hosted by countries of Africa. In addition, the growing reluctance of receiving countries in Africa to grant asylum and refugee status on a prima facie basis has also contributed to the reduction of official numbers of refugees hoisted by other 
countries on African soil (Zlotnik, 2004). Many of them therefore sought asylum and protection in a number of Western countries including Canada. The refugee influx into Canada from Africa started in the mid 1980s reaching a peak in the early 1990s when political repression and social and economic instability were rampant and prevalent in most African countries (Zlotnik, 2004; Boyd, 1999). There are about 20,000 individual refugees annually in Canada representing a little less than I0\% of total immigration into Canada (Citizenship and Immigration Canada, 1994).

The literature is replete with numerous studies on refugee movements around the world and on settlement services provided to refugees in host societies (see Keely, I992; Loescher and Loescher, I994; UNHCR, 1997). There is however a dearth in the literature on an important, but often overlooked, aspect of the lives of former refugees in host societies: their burning desires and quick attempts, in their post-refuge years to shed the refugee labels, and to reconstruct new identities, different from the refugee label and identity which many regard as stigmas. Around the world, images that are flashed on television screens and in newspapers portray refugees mainly in negative light: poor, hungry-looking and malnourished. A large number of Africans who arrived in Canada in the late 1980s and 1990s as refugees who were the subjects of this study, were very well educated professionals who escaped from their countries due to political repressions and persecutions in their countries of origin (Bauder, 2003; Grant, 2005b; Li, 200I; Mulder \&Korenic, 2005). These do not fit the usual images that are portrayed about refugees as stated above. It is no wonder that this section of the refugee population in Canada have been eager to shed the refugee label as soon as their claims to refugee status are accepted.

This study is therefore an attempt to shed light on this important aspect of the settlement lives of refugees in host societies, especially Canada. It focused on a group of African refugees who arrived in the Canadian cities of Montreal and Toronto between the late 1980s and mid 1990s. It begins with an overview of the United Nations Convention and Protocols on Refugee Protection, refugee movements into Canada from the 1980s to the early1990s, and Canada's Refugee Protection system which administers refugee claims in Canada. A brief look is taken at refugee sponsorships programs by the Canadian government and private-sponsoring organizations of refugees into Canada. This is in addition to those making refugee claims at Canada's ports of entry as well as those that make in-land refugee claims. Thirdly, the methodology and theoretical framework that guided the study are presented. The study then takes a look at settlement and integration services that are provided to refugees and new immigrants in Canada. Next, the findings from the study, which include narratives from the participants are presented. The final section discusses the findings from the study and concludes with some recommendations for assisting this new population groups not only in Canada, but in countries that receive and host refugees.

\section{United Nations Convention relating to the status of Refugees}

Adopted on 28 July I95I by the United Nations Conference of Plenipotentiaries on the Status of Refugees and Stateless Persons, the Convention stipulates that:

Any person who by reason of a well-founded fear of persecution for reasons of race, nationality, religion, membership in a particular social group or political opinion is outside his country of origin or nationality and is unable or unwilling by reason of such fear, to return toor avail himself/herself of the protection of that country, or

(b). Not having a country of nationality, is outside the country of his former habitual residence and is unable or, by reason of such fear, is unwilling to return to that country (UNHCR, 2007; Loescher and Loescher, I994). 
Persons in need of protection as stipulated in the UN Convention are people whose removal to their home countries would subject them personally to a danger of torture, a risk to their life, or a risk of cruel and unusual treatment or punishment (UNHCR, 1997).

\section{Refugee Claimants and Refugees}

This study deals with two types of refugees: refugee claimants and refugees. A refugee claimant is a person who considers himself/herself as fitting the UN Convention Refugee definition and seeks/applies to another country he/she considers safe for protection under the UN Convention on refugees. Such a person is willing to remain permanently in the country to which he/she applies for protection with the hope of starting a new life (Loescher and Loescher, I994).

Millions of people are on the move around the world as a result of wars, civil strifes, political repression, climatic changes/natural disasters, and famine. Refugees for purposes of this study are former "refugee claimants" who have been deemed or accepted as refugees by the new host country to which they applied for protection as fitting the United Nations Convention on Refugees. They may also be persons who were sponsored into a host society by government or private organizations or agencies from refugee camps around the world. Such persons are those that had escaped from their former countries of origin or habitual residence, living in another country and are deemed to be facing danger to their lives if returned to those former countries. These are usually referred to as sponsored refugees(UNHCR, 1997c; Loescher and Loescher, 1994).

\section{Canada's Refugee Determination Process}

Canada has an obligation to grant protection to Convention Refugees and other persons in need of protection. This is because Canada has signed a number of United Nations Conventions, including:

- the 195I Convention Relating to the Status of Refugees

- the 1967 Protocol Relating to the Status of Refugees

- the 1984 Convention Against Torture and other Cruel, Inhuman and Degrading Treatment or Punishment

Canada's Refugee Determination process has evolved and undergone dramatic changes from the mid-1980s (Heckman, 2009). The Immigration and Refugee Protection Act governs matters concerning immigration and refugee protection in Canada, including much of the work of the IRB. The Act came into force on June 28, 2002, replacing the previous Immigration Act of 1976.

Persons may claim refugee status at any "point of entry" into Canada: Land Borders, Airports, and Sea Ports. There are also those persons who make In-LandRefugee Claims. These are persons who have arrived in the host country earlier under different circumstances and may make a "refugee claim" to the appropriate immigration offices or offices designated for that purpose if they have reason to believe that they cannot return to their country of origin or habitual residence for reasons underlined in the UN Convention on refugees (Citizenship and Immigration Canada, 2009). In either situation, the refugee claimant is examined first by an Immigration Officer at the point of entry for eligibility to make a refugee claim. This is the first stage of the refugee claim that determines "admissibility" grounds of the Refugee Claimant. The officer may refuse the refugee claim on any of the following grounds: security risk; claimant is deemed to have committed crimes against humanity either in times of peace or war; serious criminality; health reasons; or inadmissible family member. If the claimant is deemed admissible, the claim is then referred to the Immigration and Refugee Board (IRB) for Adjudication (Canadian Council for Refugees, 2003). 
Established in 1989, the Immigration and Refugee Board (IRB), Canada's largest administrative Tribunal, is a quasi-judicial Commission which is supposed to be independent of both Citizenship and Immigration Canada and the Canada Border Services Agency (Heckman, 2009, Matas, 1989). Ithas four Divisions:The Immigration Division; Immigration Appeals Division; Refugee Protection Division; Refugee Appeals Division. It is the Refugee Protection Division that hears and determines refugee claims referred to it by the Immigration Officers that examined the claimants at the points of entry or points of refugee claim. These hearings were, during the period covered by this study, held before Refugee Panels consisting of two Refugee Board Members; a Refugee Hearing Officer (RHO) representing the government; the refugee claimantand his/her legal representative. If the IRB Adjudicating panel accepts the claimant's story, it issues a decision recognizing the refugee claimant as a refugee under the United Nations Convention. The refugee claimant (now recognized as a conventionrefugee is then allowed to apply to Citizenship and Immigration Canada for permanent residence status. If the IRB disbelieves the claimant, it issues a negative decision stating that the claimant's claim has no "credible basis" and is therefore not recognized as a refugee under the United Nations Convention (CCR, 2003). For the purpose of this study, the focus will be on those that are accepted as Convention Refugees.

There has been constant criticism in Canada over the years on the work of the IRB especially appointments to the Board and the process of adjudication (Matas, 1989). Refugee and immigration advocates in Canada have for years complained about the competence of some of the personnel appointed to the Board. Some of the complaints and accusations, relevant to this study, have centred around suspicions and concerns of incompetence and bias attitudes of some Board members towards refugee claimants (Heckman, 2009). The IRB adjudication process has over the years been engulfed in lengthy delays during which some claimants have had to wait for periods ranging from two to five years to have their claims heard (Hathaway, I99I; 2005). These long periods of waiting have created uncertainties and a lot of stress among refugee claimants, many of whom were separated from their families as at the time they arrived in Canada as refugee claimants or sponsored refugees (Canadian Task Force on Mental Health Issues Affecting Immigrants and Refugees, 1988).

\section{Methodology}

A qualitative research approach was the preferred choice in this study because it falls in the realm of phenomenology which, according to van Manen (1997), is the study of lived experience. Reflection on lived experience is always recollective; it is a reflection on experience that is already passed or lived through (van Manen, 1997). This study is therefore about the lived experience of its participants: former refugees and refugee claimants from Africa living in Canada. The research design and methodology therefore recognized the participants as expert knowers in their own lived experiences. The research process therefore recognized the expertise of the participants, through interviews which explored their ideas and understandings on their journeys, often painful, from their original homelands to Canada and the long struggles to seek acceptance and protection. It also focused on the second phase of their life's journeys to reconstruct new identities in their new homelands.

The study adopted the method of open-ended (in-depth) ethnographic interviews, which, according to Denzin and Lincoln (1998), is one of the mostcommon and powerful ways to grasp the meanings that people ascribe to their dailylives. The interview questions were designed to generate not only answersover the meanings that the interviewees have attached to their migration experiences as refugees but also their personal stories and accounts of life historiesand experiences in new societies. Secondary data included Canadian government statistics and annual immigration and refugee reports, 
reports and minutes of meetings of refugee community organizations and newspaper articles. A combination of purposive and snowballing sampling techniques was applied.

The researcher, who arrived in Canada in the late I980s as a refugee claimant himself knew a number of people in the communities identified. He contacted a number of former refugee claimants from the communities who also recommended other potential participants who also agreed to participate in the study. The researcher also attended a number of meetings of some of the refugee communities in a participant observer status. There was trust between the researcher and participants as the latter regarded the researcher as one of us who understood our struggles.

\section{Theoretical Framework}

The Critical Race Theory's tenet of counter story telling was the theoretical framework that guided the study. Critical race theory gives voice to marginalized people to tell their stories and experiences within a framework where the center of analysis is the narrative (Grant and Asimeng-Boahene, 2006). As a former refugee claimant in Canada who has experienced most of the issues that the participants alluded to, I find the use of counter-story telling very relevant to the lived experiences of the subjects of this study.

Critical Race Theory's tenet of counter-storytelling refers to the illumination of the cultural and personal narratives, family histories, and metaphorical stories that present a contrast to dominant societal narratives about race. These stories are viewed as central sources of information necessary for an authentic and comprehensive understanding of racial stratification and subordination (Dixson and Rousseau, 2006). Given that storytelling is a significant aspect of human communication, CRT has advocated for marginalized people to tell their often unheard and unacknowledged stories and for these perspectives to be applied to the existing dominant narratives that influence the law (Solorzano and Yosso, 2002). Delgado and Stefanic (200I) also describe CRTs tenet of storytelling/counterstorytelling as a process of naming one's own reality. In the case of refugees, they are the only ones who can tell and re-enact the experiences that form their reality from their countries of origin or former places of habitual residence to the new societies to which they have run to seek protection and opportunities to start new lives.

To get accepted as Convention Refugees in Canada's Refugee Determination system, refugees claimants have to recall painful experiences to tell and retell their stories to people (Immigration Officials and Refugee Board Members) who may have no such experiences and who sometimes decide not to believe the stories the refugees have to tell because they sound too much out reality for these immigration and refugee hearing officials (Matas, 1989).

\section{Research Participants}

The participants in this study were sixty persons of African origin who had arrived in Canada as refugee claimants from the mid 1980s up to the mid 1990s. They were from Ghana and Nigeria in West Africa, Democratic Republic of Congo (former Zaire) in Central Africa, and Somalia in the Horn of Africa. The researcher, a former refugee, was a former resident of Montreal, frequently visiting Toronto and knew a number of former refugee claimants in those cities. There were large numbers of refugees and refugee claimants from the above countries in the two cities during the period of this study. Thirty participants from the former refugee communities in Montreal participated in the study. Ten participants each were selected from the Ghanaian and Somalian communities and five each from the Congolese and Nigerian communities respectively. 
An equal number of thirty participated in the study from Toronto. These were from three communities: ten each from the Ghanaian, Somalian and Nigerian communities. With the exception of the Somalian group, all the other participants in the study arrived in Canada as refugee claimants. Of the ten participants of Somalian origin in the study, six had arrived in Canada as refugee claimants while eight had been sponsored to Canada from refugee camps in Kenya.Most of the participants were interviewed about a year or two after the acceptance of their refugee claims or after their arrival in Canada as sponsored refugees. All the participants were interviewed again about three to four years after the first interviews. They had, as some of them put it, "metamorphosed" from refugees, to permanent residents of Canada and becoming Canadian citizens.

In all, the study interviews took place over a period of about six years. All the participants were interviewed twice, the second being follow-up interviews, on their agreement, to check on how they were doing in their new "identities" as "Canadian citizens" and engaging in new vocations or professions.

\section{The Refugee Resettlement and Integration process in Canada}

When a refugee claimant or refugee family is finally accepted to stay in Canada for protection, and permanently, they are then entitled to services provided by an array of Settlement Agencies that can be found in all the major cities and urban centers in Canada where refugees have been settled (Abu-Laban et al, 1999; Indra, 1993; Satzewich, 1993). Refugees that arrived on their own in Canada are usually referred to Provincial health and Social Services authorities for assistance. The Government Assisted Refugees (GARs) receive 12 months of income and settlement support from the Canadian Federal government (Citizenship and Immigration Canada, 2008). The Private Sponsored Refugees (PSRs) receive settlement support from their sponsoring groups and organizations which include housing. However all the refugee categories are entitled to receive health and other social services, language and job search training provided by the provincial governments (CIC, 2008).

Settlement agencies and even government departments have tended to focus on the deficits of refugees instead of their strengths. Despite the educational backgrounds, language and occupational skills that most refugees come into Canada with (see CIC, 2003), they are usually regarded by host societies and their settlement agencies as lacking physical security, limited language and labour market skills, living in extreme poverty and having significant mental and physical health problems including disabilities (CIC, 2008; Indra, I993; Lamba, 2002). They also are regarded, usually not backed by data as more likely to be on welfare or social assistance (Basran, \&Zong, I998; Bauder, 2003). They are all lumped together as needing the same traditional services of housing, language training, job training and job search (Lamba, 2003; Li, 200I; Reitz, 200I; Zetter, 1999). It is a one-size-fit all approach.

It is this blanket image and stigma of helplessness and neediness attached to all refugees in Canada that the participants in this study struggled to shed during their post refugee acceptance periods.

\section{Findings/Discussion}

In this section I analyze the view presented by the study participants with the objective of teasing out some significant emerging themes. The refugee experience is often characterized as uprooting and traumatic, which is true. They may have experienced war, persecution, imprisonment, displacement, trauma, rape and torture, among others (Lamba, 2003). In their new host societies, refugees continue to deal with the effects of the above as well as social isolation and exclusion, conflicts with cultural expectations and mainstream institutions, role changes, identity crises, and a social reconstruction of the concept of 'home', (Bernier, 1992). 
It was echoed over and over again by the study participants how they resented the negative refugee label and stigma and were eager to shed it at the earliest opportunity. Lamba(2003) points out that because refugees are often admitted due to a collective traumatic experience, their new identities frequently and traditionally come to be defined via this collective cause. Government personnel, settlement service providers, and even researchers have all being guilty of reducing groups of refugees, wherever and whatever backgrounds they come from, to a single category of needy and helpless persons (Daniel \& Knudsen, 1995). In so doing, their distinctive life stories and histories, the push and pull factors for their escape, personal goals, individual needs, aspirations and ambitions are ignored or minimized (Zetter, I999). Furthermore, as Gold (1993) point out, simplistically characterizing refugees as persons in need can have significant negative consequences.

Other authors (see also Mazur, I988; Kuo\& Tsai, 1986) have also maintained that socially constructed expectations of refugee passivity and dependence create institutions and procedures that can discourage refugees from taking control of their lives. It leads to a situation where the thinking of settlement services and researchers come to revolve around lost capacity of refugees who are then viewed in only dependent roles, characterized by need and helplessness (Mazur, 1988). It is these images and perceptions that the former refugee participants in this study have been struggling to shed and overcome. The following narratives from some of the participants illuminate this point:

Escaping from the land of my birth...finding myself in Canada as a refugee is something that I never dreamt will happen to me. In Canada the images of refugees that are shown on television and in newspapers are those of hungry-looking, helpless people in camps. I never lived in a refugee camp. I was never hungty. I was a well-educated person holding a top professional job at home. It is the unfortunate political circumstances there that forced me to escape for my life. All I need here in Canada is protection and the chance to pursue my career which I am surely qualified for. To equate me to the category of a hungry-looking, helpless uneducated person coming from a refugee camp really hurts. You see, watching these pictures and reading about these in newspapers here contributes in lowering your self esteem

From another:

They never give us a chance here to prove ourselves as fit for careers that we have trained in prior to our coming to Canada as refugees. Whenever we go to some of the settlement agencies, they don't bother to enquire about our background. I have had all my education up to university level in English, but they keep referring me to ESL classes which I really don't need. Honestly, the settlement agencies did nothing for me. I had to struggle for information myself as to how to further my education. In fact I was determined to get some Canadian education to boost the ones I came with and move away from this distressing refugee stigma

\section{New Identity Construction in host societies}

Identities are social constructions. As defined by Hall (1996), identities are about questions of using the resources of history, language, and culturein the process of becoming rather than being: not 'who we are' or 'where we camefrom', so much as what we become, how we have been represented and how thatbears on how we represent ourselves.Always in process, identities undergo constant transformations and are increasinglyfragmented, fractured, and multiply or reconstructed across different, often antagonistic,discourses, practices, and positions Hall, 1994). Fragmented and shifting asthey are, however, identities strive for a closure, a belief in internal coherence, anda sense of eternity (Frith, 1996), which can be achieved through retelling the stories ofthe past, sometimes painful as in the case refugees, and imagining a new secure 'homeland'. 
Participants in this study became engaged in struggles at creating new identities, from their assigned refugee labels which, as indicated above, many resented due to the stigma attached to it. But reconstructing new identities in foreign, often strange lands is not an easy undertaking. Hall, (I994) emphasises this point by pointing out that diasporic identities are constantly producing and reproducing themselves anew alongitineraries of migrating,but also re-creating the endless desire to return to lost origins. Diaspora members, living on culturalborderlands or interstitial zones, cluster around remembered or imagined'homelands', practise 'authentic home cultures', form ethnic communities, so as tore-root their floating lives and reach a closure in making sense of their constantlychanging subjectivities (Frith, I996; Hall, 1996).

Some of the study participants attested to how they struggled to construct new identities from the refugee labels. All the refugee communities which were part of this study found the need, earlier on their arrival in Canada, to form advocacy groups clustered around the refugee label. There were the Ghana Refugee Union, Montreal formed in 1987, The Ghanaian Refugee Association, Toronto, formed in 1989, The Nigerian Refugee Association, Montreal formed in 1990 and a number of Somali Refugee Associations in Montreal and Toronto in the early 1990s.

It emerged from the study that most newly-arrived refugee claimants and refugees in the above communities were eager to become members of these refugee associations when they first arrive in Montreal and Toronto. They became active members of the associations to assist in their advocacy work aimed at getting fair and speedy refugee hearings for their members. However, most of the same members who were active members of their refugee advocacy groups showed little or no interest in the same associations when their refugee processes were over and they became permanent residents. The associations were thus compelled to change their names, the Ghanaians from the Ghana Refugee Union to the Ghanaian-Canadian Association and the Nigerians from the Nigerian Refugee Association to the Nigerian-Canadian Association. The Ghana Refugee Association in Toronto completely folded up as most of the members lost interest altogether in the need for any grouping. The researcher attended some meetings of the Ghanaian-Canadian Association in its new identity in the mid to late 1990s. Some excerpts from the narratives of respondents attest to the above:

Most of our members have got their refugee claims accepted and are now permanent residents. We need now to move from the advocacy role for refugee acceptance of the former association to a new role of assisting our members with pressing settlement issues of education and employment and most importantly with their new struggles to sponsor their families some of whom have been separated for over five years. We also feel the urgent need to repackage the image of the association to retain our membership because many of them do not want to be associated with the refugee label anymore. Now they find it demeaning to be called refugees. It is ironic though since that is the label that got them accepted to stay permanently in this country. Well, we have no choice. We have to change with the times

Another interesting narrative from one participant:

During the three years that I was waiting for my refugee claim to be accepted, I had this Social Insurance Card number starting with a '9'. It was like the number '9' was a dirty identity. Wherever you go, from looking for jobs or getting some government service, the moment they see your card with the '9', they look at you differently, I mean not in any positive light. So when I got my permanent residence paper, the first thing I did was to apply for a new Social Insurance Number. Now nobody looks at me with strange eyes or ditty looks when they see my card number starting with a ' 2 '. Hei, man, it's not a nice experience in this country being a refugee 
Most of the study participants also lamented the fact that their lives were in limbo when they had the status of refugee claimants and refugees. Their children (if they had) could go to school, but they (the adults) were not allowed to continue their education because as refugee claimants, they were regarded as temporary residents. No wonder most of the participants pointed out that their first actions as accepted refugees or permanent residents were to rush to continue their education or get into job and skills training programs. Another narrative from a participant:

\begin{abstract}
Some of the embartassing moments of my life as a refugee here in Canada was being asked many times whether I speak English. Most occasions I have tried to explain to people that I have had all my education in English up to having a Master's Degree, and the official language of my former country is English. They don't pay attention. It's like the only thing they saw about me is being a refugee who needs help with food and how to speak English. It was embarrassing. In fact I don't want to remember those days.
\end{abstract}

When new comers move to a new society, they are likely to live in places where they find people who look like them in terms of ethnicity or cultural backgrounds (Owusu, I999). This is sometimes out of the need for comfort, support and security (Simon, 1998). However, as some study participants point out, the places that they lived in the cities of Montreal: Parc Extension, Cote-des-Neiges, Mountain Sights and Pierrefonds came to be stigmatized as the refugee ghettos. In Toronto, study participants had the same complaints of their neighbourhoods being labelled and stigmatized. Most of the Ghanaians lived in the Jane and Finch suburb in Etobicoke, while most Somalis lived in the Dixon and Kipling area all of which were labelled and stigmatized as refugee ghettos. The following narratives from some participants highlight their frustration on the ethnic ghetto stigmas.

I constantly prayed for the day when my refugee status will be over so that I could further my education and get a good job to enable me move my family out of the Jane and Finch area. This is not a bad neighbourhood. Compared to the number of people who live in that area, the refugees were insignificant, but because the refugees were concentrated in a number of high rise buildings which were close to each other, the whole neighbourhood came to be associated with refugees. When you mention to someone that you live in Jane and Finch, they look at you differently. So we got our permanent residence, we moved very quickly to Brampton in the West End, far away from Jane and Finch. In fact I don't want to remember that area and I don't let my children go back there even though most of their friends still live there.

From another participant:

The Canadian media tried to portray the Somalian refugees who lived in the Dixon and Kipling area in Toronto as contaminating the neighbourhood. The CBC (Canadian Broadcasting Corporation) even did a documentary on us. It was a very bad Television series. They called it A Place called Dixon. The message the media sent to Canadians was that Somalian refugees were destroying their nice neighbourhood. We were very stressed and confused during this period. We had committed no crimes except coming to Canada and to Toronto as refugees. But the question is: what is wrong with many Somalis living in the same area? We need each other for support. Why don't they complain when many White people lived in the same neighbourhood? Something is wrong her, man.

\title{
II. Conclusion
}

When refugees, who are people engulfed in forced migration due to situations of persecution, war, insecurities and trauma move to peaceful and sometimes wealthy countries, they have high expectations 
for better lives for themselves and their families. They have hopes that their children will have access to opportunities for better lives, different from the disrupted and insecure ones they (adult refugees) were subjected to before arriving in their country of refuge. As this study found out, these hopes of a better, secure future and opportunities for their children depend, to a large extent on how successfully the parents, who arrived in the host society as refugees, navigate their way through the system in their new society. As the findings from this study show, the opportunities that are available to them and their children are embedded within a complex broader social and cultural environment that stigmatized them because of their migration backgrounds. They engage in multiple tasks of trying to shed the painful memories of their past which brought them to Canada as refugees and another process of shedding this stigma. As many of the study participants lamented, this process saps a lot of their time and energy.

An important and unique aspect of this study was its focus on how refugees who come to Canada, some of them well-educated professionals, experiencing stigmatization and labelling react with destigmatization moves and gestures. It should be realized that refugees are people first, like everyone else. They are just unfortunate to have found themselves on the wrong side of history and life's journey at some points in their lives. What they need in their new societies is support, understanding and encouragement to enable them rebuild their disrupted lives. They certainly do not need stigmatization and labelling which may be another form of the persecution and harassments they escaped from and hope to leave behind them.

\section{References}

Abu-Laban, B; Derwing, T; Krahn, H; Mulder, M; \& Wilkinson, L. (1999). The settlement experiences of refugees in Alberta: A study prepared for Citizenship and Immigration Canada, Edmonton, AB: prairie Centre of Excellence for Research on immigration and Integration and Population research Laboratory.

Basran, S. G., \&Zong, L. (1998). Devaluation of foreign credentials as perceived by visible minority professional immigrants. Canadian Ethnic Studies, 30(3), 6-23.

Bauder, H. (2003). "Brain Abuse", or the devaluation of immigrant labour in Canada. Antipode, 35(4), 699-717.

Bernier, D. (1992). Indochinese refugees: A perspective from various stress theories. In Ryan, A. S. (ed). Social Work with Immigrants and refugees. New York: Harworth.

Boyd, M. (1999).Gender, Refugee Status and Permanent Resettlement. Gender Issues, vol. I7, no. I, Winter 1999.

Canadian Council for Refugees.(2003). State of Refugees in Canada. Retrieved from: www.web.ndt/ $\mathrm{Cccr} / \mathrm{state} / \mathrm{html}$. November 2010

Canadian Task Force on Mental Health Issues Affecting Immigrants and Refugees. (1988). After the door has been opened: Mental health Issues Affecting Immigrants and Refugees in Canada (No. Ci96-38/1988E). Ottawa: Ministry of Supply and Services.

Citizenship and Immigration Canada.(2009). Refugees. Retrieved October 2010, from http://www.cic.gc.ca/english/refugees/index.asp

Citizenship and Immigration Canada. (2008). Canada's Refugee Resettlement Program Overview, Challenges and Priorities, CIC, Ottawa

Citizenship and Immigration Canada. (2003). Facts and Figures 2002: Immigration overview. Ottawa: Minister of Supply and Services.

Citizenship and Immigration Canada. (1994). Refugee Claims in Canada and Resettlement from Abroad.Statistical Digest. Nov. 1994. Ottawa, Canada

Connors, J. (1997). Legal Aspects of Women as a Particular Social Group: International Journal of Refugees 9 (Autumn, special issue supplement): II4-I28.

Daniel, V. F., \& Knudson, J. C. (1995). Mistrusting Refugees. Berkley, CA: University of California Press.

Delgado, R. and Stefancic, J. (200I).Critical Race Theory: An Introduction, NYU Press.

Denzin, N. K., \& Lincoln, Y. S. (2000). The Discipline and Practice of Qualitative Research. In Denzin, N. K., \& Lincoln, Y. S. (eds. 2000).Handbook of Qualitative Research. Thousand Oaks: Sage. 
Dixson, A. D. and Rousseau, Celia.K. (eds). Critical Race Theory in Education: All God's Children Got a Song. New York: Routledge, 2006.

Frith, S. (I996).Music and identity.In: S. Hall \& P. du Gay(Eds.). Questions of cultural studies (pp.I08-II7). London: Sage.

Grant, P. R. (2005b). The devaluation of immigrants' foreign credentials: The psychological impact of this barrier to integration into Canadian society. A final report to the Prairies Metropolis Center.http://www.pcerii.metropolis.net/, November, 2009.

Grant, R. A., andAsimeng-Boahene, L. (2006). Culturally responsive pedagogy in citizenship education: Using African proverbs as tools for teaching in urban schools. Multicultural Perspective(8)4: 17-24.

Hall, S. (I994). Cultural identity and diaspora. In P. Williams \& L. Chrisman (Eds.), Colonial Discourse andPostcolonial Theory: A Reader (pp. 392-403). New York: Columbia UP.

Hall, S. (I996). Introduction: who needs identity? In S. Hall \& P. du Gay (Eds.), Questions of Culturalidentity(pp. I-I7). London: Sage Publications.

Hathaway, J. C. (2005). The Rights of Refugees under International Law. Cambridge: Cambridge University Press.

Hathaway, J. C. (I99I). The Law of Refugee Status. Toronto: Butterworths.

Heckman, G. P. (2009). Canada's Refugee Status Determination System and the International Norm of Independence. Refuge, vol. 25(2), p. 79-I02.

Indra, D. M. (I993). The spirit of the gift and the politics of resettlement: The Canadian private sponsorship of South East Asians. In Robinson, V. (ed). The international refugee crisis: British and Canadian responses, p. 229-254. London: Macmillan.

Keely, C. B. (1992).The Resettlement of Women and Children Refugees.Migration World 20 (4): I4-I8.

Kouritzen, S. (2000).Bringing life to research.TESL, Canada Journal, I7(2), I-23.

Kuo, W. H., \& Tsai, Y. (I986). Social networking, hardiness and immigrants' mental health. Journal of Health and Social Behavior, 27, I33-I49.

Lamba, N. K. (2003). The employment experiences of Canadian refugees: Measuring the impact of human and social capital on employment outcomes. Canadian Review of Sociology and Anthropology, 409I), 45-64.

Li, P. (200I). The market worth of immigrants' educational credentials.Canadian Public Policy, 27(I), 23-38.

Loescher, G. and Loescher, A. D. (I994). The Global Refugee Crisis: A Reference Handbook. Santa Barbara, CA: ABC-CLIO.

Matas, D. (1989). Closing the Doors: The Failure of Refugee Protection inCanada.Toronto: Summerhill Press.

Mazur, R. E. (I988). Refugees in Africa: The role of sociological analysis and praxis. Current Sociology, 24 , I-24.

Mulder, M., \&Korenic, B. (2005).Portraits of immigrants and ethnic minorities in Canada: Regional comparisons. Alberta: PCERII.

Owusu, T. (1999). Residential Patterns and Housing Choices of Ghanaian Immigrants in Toronto, Canada. Housing Studies, vol. I4(I), 77-97.

Reitz, G. J. (200I). Immigrant skill utilization in the Canadian labour market. Journal of International Migration and Integration, 2(3), 518-548.

Satzewich, V. (1993). Migrant and immigrant families in Canada: State coercion and legal control in the formation of ethnic families. Journal of Comparative Family Studies, 24(3), 315-338.

Simon, P. (1998). Ghettos, Immigrants, and Integration: The French Media. Neth. J. of Housing and the Built Environment, vol. I3(I).

Solorzano, D. \&Yosso, T. (2002). "A Critical Race Counterstory of Affirmative Action in Higher Education." Equity and Excellence in Education, 35, I55-I68.

UNHCR. (2007). Convention and Protocol Relating to the Status of Refugees. Retrieved May 2009, from http://www.unhcr.org/3b66c2aaI0.pdf.

UNHCR. (2007c). The State of the World's Refugees: A Humanitarian Agenda. Oxford: Oxford University Press.

Van Manen, M. (1997). Researching lived experience. Edmonton, Alberta: The Althouse Press.

Zetter, R. (1999). International perspectives on refugee assistance. In Ager, A. (ed), Refugees: Perspectives on the experiences of forced migration, p. 46-82. New York: Pinter 
Zlotnik, H. (2003). Migrants' rights, forced migration and migration policy in Africa. Paper Presented at the Conference on African Migration and Urbanization in Comparative Perspective held in Johannesburg, South Africa, June 2003. 